\title{
Radionuclide activities in sediments on the northern coast of Spitsbergen
}

\author{
Barbara WOJTASIK ${ }^{1}$, Sławomir ŚWIRYDOWICZ2*, Dorota BURSKA ${ }^{3}$ \\ and Kamil NOWIŃSKI ${ }^{4}$
}

${ }^{1}$ Department of Genetics and Biosystematics, Faculty of Biology, University of Gdańsk, Wita Stwosza 59, 80-308 Gdańsk, Poland <b.wojtasik@ug.edu.pl>

${ }^{2}$ Department of Physics and Biophysics, Medical University of Gdańsk, Dębinki 1, 80-211 Gdańsk, Poland <swiryd@gumed.edu.pl>

${ }^{3}$ Department of Marine Chemistry and Environmental Protection, Faculty of Oceanography and Geography, University of Gdańsk, Marszałka Pitsudskiego 46,81-378 Gdynia,Poland <dorota.burska@ug.edu.pl>

${ }^{4}$ Department of Limnology, Faculty of Geography and Oceanography, University of Gdansk, ul.Bażyńskiego 4, 80-952 Gdańsk, Poland <kamil.nowinski@ug.edu.pl>

* corresponding author

\begin{abstract}
The specific activity of natural gamma emitters like actinium $\left({ }^{228} \mathrm{Ac}\right)$, bismuth $\left({ }^{212} \mathrm{Bi},{ }^{214} \mathrm{Bi}\right)$, lead $\left({ }^{212} \mathrm{~Pb},{ }^{214} \mathrm{~Pb}\right)$, potassium $\left({ }^{40} \mathrm{~K}\right)$, radium $\left({ }^{224} \mathrm{Ra}\right)$, thallium $\left({ }^{208} \mathrm{Tl}\right)$ and artificial radioisotope caesium $\left({ }^{137} \mathrm{Cs}\right)$ was measured in 2005 in the surface layer of marine sediments in the northern Svalbard: Wijdefjorden, Woodfjorden, Vestfjorden and Bockfjorden as well as in the freshwater reservoirs in Andre Land. Nonuniform spatial distribution of these radionuclides was found. Sediment sample from Bockfjorden had the highest specific activities of all natural radionuclides. The specific radioactivity of ${ }^{137} \mathrm{Cs}$ was much lower than specific radioactivities of natural radionuclides but there were differences between investigated locations. The distribution of ${ }^{137} \mathrm{Cs}$ is similar to persistent organic pollutants of the lake sediments in the area.
\end{abstract}

Key words: Arctic, Svalbard, natural radionuclides, ${ }^{137} \mathrm{Cs}$, fjords, freshwater sediments, marine sediments.

\section{Introduction}

Naturally occurring radionuclides of terrestrial origin are present in every material in our surrounding. Its concentration in the environment depends on the type of rocks from which soil originates. This causes significant differences in concentrations of particular nuclides (Dragović and Onjia 2006). For example, 
radioactivities of ${ }^{40} \mathrm{~K}$ and ${ }^{226} \mathrm{Ra}$ in the Northern Europe ranged between 140 and $1150 \mathrm{~Bq} / \mathrm{kg}$ as well as 6 and $310 \mathrm{~Bq} / \mathrm{kg}$, respectively (UNSCEAR 2000).

Measurements of the radioactivity of gamma emitters in the Arctic have been completed in selected regions only, for example in the Barents Sea (Føyn and Sværen 1997). Different radioactivity levels of anthropogenic ${ }^{137} \mathrm{Cs}$ in soils, bottom sediments and living organisms have been also noted (Gwynn et al. 2004; Andersen et al. 2006; Stepanets et al. 2007; Zaborska et al. 2010). Measurements of radioactive isotopes appearing after nuclear tests in the near-bottom waters were performed intensively in the 1950s and at the beginning of the 1960s. The Chernobyl fallout in 1986 has created clear time markers in sediments and allowed determination of recent sedimentation accumulation rates (Namiotko et al. 1993; Ilus and Saxen 2005). The sea currents have transported caesium from the Gulf of Finland and the Gulf of Bothnia into the Baltic Proper and out of the Baltic into the North Sea (Ilus 2007). In the Barents Sea, the main sources of anthropogenic radioactive contaminants are: atmospheric fallout (including Chernobyl fallout), discharges from the nuclear industry in Europe, assumed contribution from land-based sources in the northern Russia, dumped radioactive material of the former USSR and contribution from the Chernobyl accident via the Baltic Sea (Føyn and Sværen 1997). Anthropogenic radioactive isotopes as well as their migration are investigated more often because of their potential dangerous influence on humans (UNSCEAR 2000; Strand et al. 2002; AMAP 2003, 2004). Although data concerning natural gamma emitters in Svalbard are still lacking, Gwynn et al. (2004) reported ${ }^{137} \mathrm{Cs}$ concentrations from seawater and sediments from several sites in Kongsfjorden and Isfjorden.

\section{Study area}

In order to analyse concentrations of gamma emitters in the surface layer of bottom sediments, three fjords that differ in morphology were selected in the northern part of Spitsbergen (Wijdefjorden, Woodfjorden and Bockfjorden). In addition, the tidal flat situated in Vestfjorden and freshwater reservoirs on the east coast of Woodfjorden (Fig. 1) were also investigated. The researched area is situated in the mixing zone of the Atlantic and Arctic waters and the region is under their diverse influence (Proshutinsky et al. 1999; Jones 2001). In Wijdefjorden, which is the most eastern of selected fjords, the Atlantic waters appear only during periods of increased activity of the West Spitsbergen Current, while the fjord is generally affected by the Arctic water. In contrary, the other fjords, i.e. Woodfjorden and Bocfjorden, are influenced by the West Spitsbergen Current for almost the entire year (Midttun 1990; Haugan 1999; Jones 2001; Løyning 2001; Walczowski and Piechura 2006, 2007).

The fjords are different in shape and therefore the samples were taken from water depths ranging from 15 to $75 \mathrm{~m}$ (Table 1). Wijdefjorden is the longest 


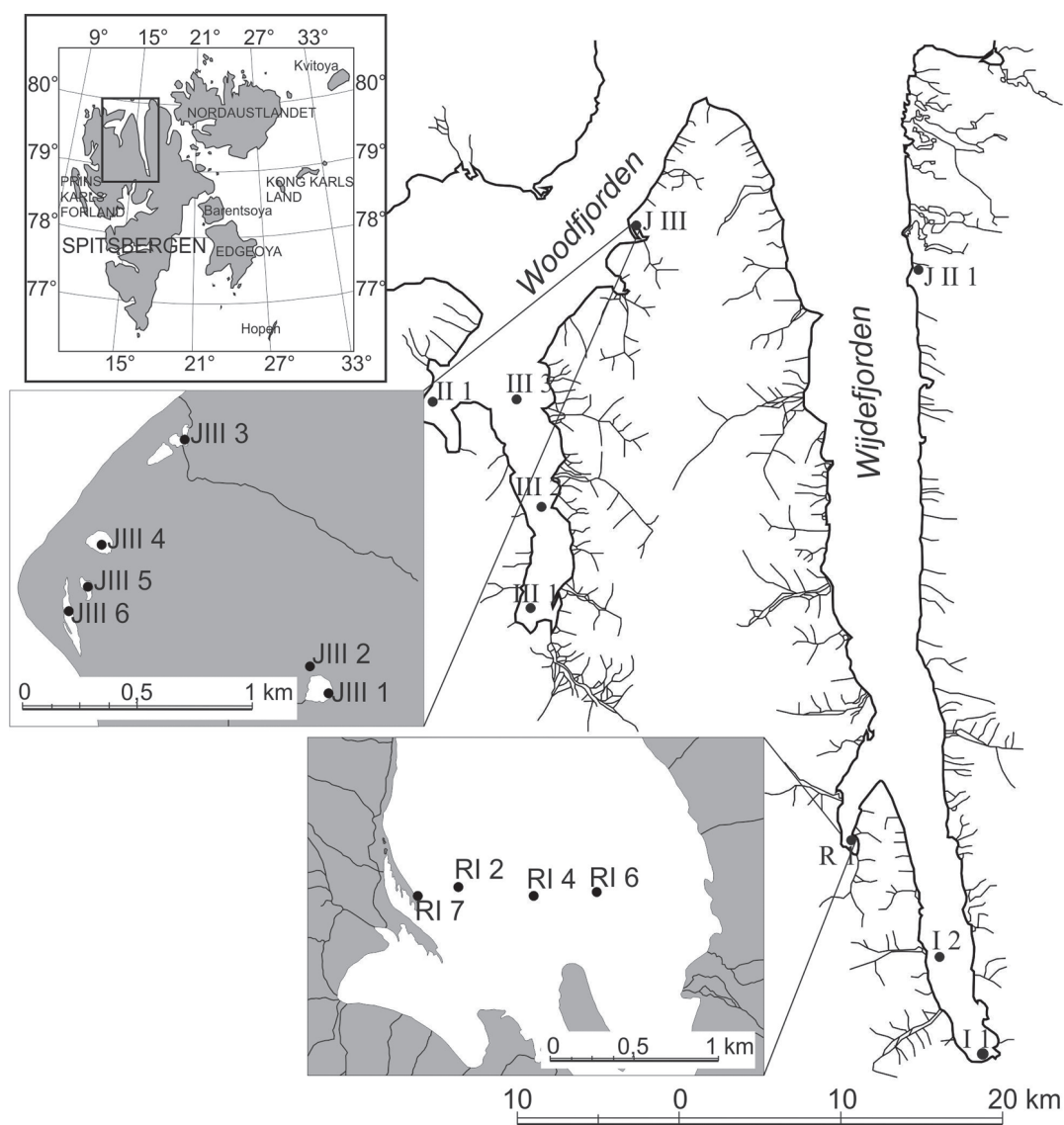

Fig. 1. Study area in northern Spitsbergen.

fjord on Spitsbergen $(120 \mathrm{~km})$ and its depth varies greatly reaching $246 \mathrm{~m}$. Vestfjorden is the western branch of Wijdefjorden. Bockfjorden is a small fjord on the western side of Woodfjorden (Fig. 1).

The tidal flat in Vestfjorden formed mainly by sediments deposited in the glacial river estuary. It is under the influence of waters of both marine and terrestrial origin, as exhibited by measured water salinities (Table 1). During a high tide, the whole plain is under water, while during a low tide a severalkilometer-wide zone of alluvial deposits becomes exposed. This site is surrounded by mountains reaching $1318 \mathrm{~m}$ a.s.l. (Skirhorg). Sediments accumulated in the tidal flat are brought in by a large river originating from the Universitetbreen and Lisbetbreen glaciers, in front of which a large end moraine and 7-kilometreslong Vestfjorden valley are situated. Suspended sediments delivered by glacial rivers cause progressive decrease of the fjord depth. Therefore, the tidal flat is now about two kilometres long. 
Table 1

Characteristic of the study area and surface sediments.

\begin{tabular}{|c|c|c|c|c|c|c|}
\hline \multirow{2}{*}{ Station } & \multicolumn{2}{|c|}{ Geographical position } & \multirow{2}{*}{$\begin{array}{l}\text { Depth } \\
\text { (m) }\end{array}$} & \multirow{2}{*}{$\begin{array}{c}\text { Temperature } \\
\left({ }^{\circ} \mathrm{C}\right)\end{array}$} & \multirow{2}{*}{$\begin{array}{l}\text { Salinity } \\
\text { (psu) }\end{array}$} & \multirow{2}{*}{$\begin{array}{l}\text { Type of } \\
\text { sediment }\end{array}$} \\
\hline & $\phi$ & $\lambda$ & & & & \\
\hline \multicolumn{7}{|c|}{ Fjord } \\
\hline I 1 & $78^{\circ} 54.40^{\prime} \mathrm{N}$ & $16^{\circ} 24.60^{\prime} \mathrm{E}$ & 16 & 2.7 & 32.0 & muddy \\
\hline I 2 & $79^{\circ} 00.40^{\prime} \mathrm{N}$ & $16^{\circ} 19.10^{\prime} \mathrm{E}$ & 60 & 2.1 & 29.3 & muddy \\
\hline II 1 & $79^{\circ} 27.30^{\prime} \mathrm{N}$ & $13^{\circ} 22.90^{\prime} \mathrm{E}$ & 54.0 & 3.6 & 34.8 & muddy \\
\hline III 1 & $79^{\circ} 18.80^{\prime} \mathrm{N}$ & $13^{\circ} 53.60^{\prime} \mathrm{E}$ & 44.0 & 2.8 & 30.5 & muddy \\
\hline III 2 & $79^{\circ} 23.60^{\prime} \mathrm{N}$ & $13^{\circ} 54.00^{\prime} \mathrm{E}$ & 75.0 & 1.2 & 31.7 & muddy \\
\hline III 3 & $79^{\circ} 28.60^{\prime} \mathrm{N}$ & $13^{\circ} 44.90^{\prime} \mathrm{E}$ & 43.0 & 4.4 & 34.1 & muddy \\
\hline \multicolumn{7}{|c|}{ Tidal plain } \\
\hline RI 2 & $79^{\circ} 06.08^{\prime} \mathrm{N}$ & $15^{\circ} 38.64^{\prime} \mathrm{E}$ & 0.3 & 4.2 & 6.6 & muddy \\
\hline RI 4 & $79^{\circ} 06.05^{\prime} \mathrm{N}$ & $15^{\circ} 39.91^{\prime} \mathrm{E}$ & 0.3 & 4.6 & 0.5 & muddy \\
\hline RI 6 & $79^{\circ} 06.06^{\prime} \mathrm{N}$ & $15^{\circ} 40.98^{\prime} \mathrm{E}$ & 0.3 & 4.5 & 3.7 & muddy \\
\hline RI 7 & $79^{\circ} 06.05^{\prime} \mathrm{N}$ & $15^{\circ} 38.42^{\prime} \mathrm{E}$ & 0.3 & 3.0 & 0 & muddy \\
\hline \multicolumn{7}{|c|}{ Lakes } \\
\hline JII 1 & $79^{\circ} 38.47^{\prime} \mathrm{N}$ & $15^{\circ} 38.40^{\prime} \mathrm{E}$ & 0.3 & 6.6 & 0.1 & muddy \\
\hline JIII 1 & $79^{\circ} 40.33^{\prime} \mathrm{N}$ & $14^{\circ} 15.40^{\prime} \mathrm{E}$ & 0.3 & 7.8 & 0 & muddy \\
\hline JIII 2 & $79^{\circ} 40.39^{\prime} \mathrm{N}$ & $14^{\circ} 15.07^{\prime} \mathrm{E}$ & 0.3 & 8.9 & 0 & muddy \\
\hline JIII 3 & $79^{\circ} 40.90^{\prime} \mathrm{N}$ & $14^{\circ} 13.38^{\prime} \mathrm{E}$ & 0.3 & 6.9 & 0 & muddy-sandy \\
\hline JIII 4 & $79^{\circ} 40.66^{\prime} \mathrm{N}$ & $14^{\circ} 12.15^{\prime} \mathrm{E}$ & 0.3 & 8.6 & 0 & muddy-sandy \\
\hline JIII 5 & $79^{\circ} 40.57^{\prime} \mathrm{N}$ & $14^{\circ} 12.06^{\prime} \mathrm{E}$ & 0.3 & 9.7 & 0 & muddy \\
\hline JIII 6 & $79^{\circ} 40.53^{\prime} \mathrm{N}$ & $14^{\circ} 11.92^{\prime} \mathrm{E}$ & 0.3 & 7.7 & 0.7 & muddy-sandy \\
\hline
\end{tabular}

Six of investigated freshwater reservoirs are situated on the east coast of Woodfjorden, north of Mushamna. One reservoir is located on the northern lateral moraine of the Nordbreen glacier extending into Wijdefjorden. Most of the studied fresh water reservoirs are thermokarst lakes formed on an impermeable layer of permafrost (Choiński 2000). Lakes are surrounded by tundra vegetation and are fed by small rivulets carrying melt water from snow and ice patches as well as from streams flowing on the thawing ground. These water reservoirs are characterized by distinctly developed recharge area and considerable instability 
of sizes resulting from violent precipitation events or their lack (Nowiński 2002). They are also characterized by the most developed vegetation, not only in the drainage basin. The stony drainage area of the JIII 1 lake is covered with sparse flora because it is situated relatively high $(57 \mathrm{~m})$ on a mountain slope. This relatively large $\left(0.012 \mathrm{~km}^{2}\right)$ and deep $(3.6 \mathrm{~m})$ lake receives drainage from the hill slope and is permanently connected to the sea. A considerably smaller lake JIII 2, which is located nearby, is periodically connected with JIII 1 . Other freshwater reservoirs in the study area (JIII 3, JIII 4, JIII 5) are open shallow lakes (up to $1 \mathrm{~m}$ ) and relatively large (up to $0.05 \mathrm{~km}^{2}$ ) collecting water from extensive drainage basins. The surrounding area is waterlogged, and covered with rampant tundra vegetation. Despite being situated $150 \mathrm{~m}$ from the sea, salinity was zero in JIII 3, JIII 4 and JIII 5, due to large quantities of melt water.

Salinity amounting to $0.7 \%$ was measured in JIII 6 , which is located in the coastal zone and is affected by oozing, seawater inflows and aerosol supply. The lake bottom and its surroundings comprise of well-sorted stone material, resulting from the sea level changes. The JIII 6 lake has no distinct inlets and outlets. It changes its size dynamically, depending on the hydro-meteorological conditions, and can even disappear in the summer as a result of insufficient water supply.

JII 1 is a kettle lake typical of moraine areas. It was formed in a small (ca $3 \mathrm{~m}^{2}$ ) and shallow depression in the bed of a dry glacial river. It is mainly supplied with water originating both from snow, glacier or dead ice within melting moraines and directly from the precipitation. Lakes situated near the glacier front are also characterized by very rapid and dynamic morphometric changes which result from relatively large moraine mobility (Churski 1974). The JIII 1 lake has no distinct water inlets and outlets, and low water salinity may result from marine aerosols.

\section{Material and methods}

Field work. - Research was carried out between July 20 and July 30, 2005 on the board of research vessel m/y Eltanin (fjords) and a small boat (lakes). The surface sediment samples $(0-5 \mathrm{~cm})$ were taken from sampling stations with an Ekmann grab of dimensions $23 \times 23 \mathrm{~cm}$. The water temperature and salinity were measured (WTW conductivity meter) on each sampling station (Table 1, Fig. 1). Bottom sediments from the tidal flats and freshwater reservoirs were taken with Kajak tube sampler.

Organic matter content (as LOI \% - loss on ignition) was measured by heating sediment samples to $550^{\circ} \mathrm{C}$ for 5 hours. The sediment samples were air-dried and the water content (W\%) was analyzed as an average loss of weight of three measurements (PN-ISO 1164 1999; Graca 2004; Drzymała 2007). 
Radioactivity analysis. - Activities of gamma-emitting radionuclides (natural and ${ }^{137} \mathrm{Cs}$ ) were measured by using a multi-channel (8 thousand channels) analyser with a germanium detector (Silena International S.p.A., Italy). The detector was cooled with liquid nitrogen. The measuring equipment was calibrated with calibration radioisotope source, containing: ${ }^{241} \mathrm{Am},{ }^{133} \mathrm{Ba},{ }^{139} \mathrm{Ce},{ }^{57} \mathrm{Co},{ }^{60} \mathrm{Co}$, ${ }^{137} \mathrm{Cs},{ }^{203} \mathrm{Hg},{ }^{54} \mathrm{Mn},{ }^{85} \mathrm{Sr}$ and ${ }^{88} \mathrm{Y}$, produced and certified by Czech Metrological Institute, Inspectorate for Ionizing Radiation.

The background radioactivity level was measured and subtracted from the radioactivities of measured samples. Sediment samples were dried at the temperature $105^{\circ} \mathrm{C}$ and then weighed, transferred into Marinelli beakers, special beakers designated to provide good measurement sensitivity (Sima 1992). The volume of sediment sample was $450 \mathrm{ml}$. The beaker with sample was placed in the measurement chamber for 16 hours. Activities of radionuclides were calculated with EMCAPLUS emulation software (Silena International, Italy).

Activities of the following gamma-emitting radionuclides were measured: actinium $\left({ }^{228} \mathrm{Ac}\right)$, bismuth $\left({ }^{212} \mathrm{Bi},{ }^{214} \mathrm{Bi}\right)$, caesium $\left({ }^{137} \mathrm{Cs}\right)$, potassium $\left({ }^{40} \mathrm{~K}\right)$, lead $\left({ }^{212} \mathrm{~Pb},{ }^{214} \mathrm{~Pb}\right)$ and thallium $\left({ }^{208} \mathrm{Tl}\right)$. The activity of particular isotope in each sample was determined on the basis of photons counting in the $\gamma$ line of the maximum radioactive disintegration yield. The energies of photon lines used to determine the activity of particular radionuclides in the samples were as follows: ${ }^{228} \mathrm{Ac}-911.2 \mathrm{keV},{ }^{212} \mathrm{Bi}-727.17 \mathrm{keV},{ }^{214} \mathrm{Bi}-609.32 \mathrm{keV},{ }^{137} \mathrm{Cs}-661.62 \mathrm{keV}$, ${ }^{40} \mathrm{~K}-1460.75 \mathrm{keV},{ }^{212} \mathrm{~Pb}-238.63 \mathrm{keV},{ }^{214} \mathrm{~Pb}-351.99 \mathrm{keV},{ }^{208} \mathrm{Tl}-583.14 \mathrm{keV}$. Activities of ${ }^{224} \mathrm{Ra}$ and ${ }^{226} \mathrm{Ra}$ were estimated not determined directly from photons counting. This is due to the overlap of the peaks in the spectrum. The peak $241.0 \mathrm{keV}$ from ${ }^{224} \mathrm{Ra}$ and the peak $242.0 \mathrm{keV}$ from ${ }^{214} \mathrm{~Pb}$ are overlapping each other. There is one resultant, wide peak in gamma spectum, it consists of the sum of counts from ${ }^{224} \mathrm{Ra}$ and ${ }^{214} \mathrm{~Pb}$. The maximum of the peak is located between $241.0 \mathrm{keV}$ and $242.0 \mathrm{keV}$. The peak location depends on the ratio of counts number from ${ }^{224} \mathrm{Ra}$ and ${ }^{214} \mathrm{~Pb}$.

We have the relationship between the counts number and location of peaks:

$$
\begin{aligned}
& N_{\text {TOT }}=N_{224 R a}+N_{214 P \dot{ }} \\
& E_{\text {TOT }}=\frac{N_{224 R a}}{N_{\text {TOT }}} E_{224 R a}+\frac{N_{214 P \dot{ }}}{N_{\text {TOT }}} E_{214 P \dot{b}}
\end{aligned}
$$

$\mathrm{N}_{\text {TOT }}$ - total amount of counts in resultant peak, $\mathrm{N}_{224 \mathrm{Ra}}$ and $\mathrm{N}_{214 \mathrm{~Pb}}-$ counts from ${ }^{224} \mathrm{Ra}$ and ${ }^{214} \mathrm{~Pb}$ respectively; $\mathrm{E}_{\mathrm{TOT}}$ - location (energy) resultant peak, $\mathrm{E}_{224 \mathrm{Ra}}$ and $\mathrm{E}_{214 \mathrm{~Pb}}$ - location of ${ }^{224} \mathrm{Ra}$ and ${ }^{214} \mathrm{~Pb}$ peak respectively, $\mathrm{E}_{224 \mathrm{Ra}}=241.0 \mathrm{keV}$ and $\mathrm{E}_{214 \mathrm{~Pb}}=242.0 \mathrm{keV}$.

From these relations we can show that: 


$$
N_{224 R a}=\frac{E_{214 P b}-E_{\text {TOT }}}{E_{214 P b}-E_{224 R a}} N_{\text {TOT }}
$$

and finally, activity of ${ }^{224} \mathrm{Ra}$ :

$$
A_{224 R a}=\frac{N_{224 R a}}{f_{224 R a}} \frac{1}{E f f_{241 \mathrm{ReV} V}}=\frac{E_{214 P b}-E_{\text {TOT }}}{E_{214 P b}-E_{224 R a}} \frac{N_{\text {TOT }}}{f_{224 R a}} \frac{1}{E f f_{24 \mathrm{ReV} V}}
$$

$\mathrm{f}_{224 \mathrm{Ra}}$ - gamma disintegration yield for line $241 \mathrm{keV}$ from ${ }^{224} \mathrm{Ra}, \mathrm{Eff}_{241 \mathrm{keV}}-$ efficiency at energy $241 \mathrm{keV}$, obtained during the calibration process.

We have a similar problem with activity of ${ }^{226} \mathrm{Ra}$. The peak $186.2 \mathrm{keV}$ from ${ }^{226} \mathrm{Ra}$ and the peak $185.7 \mathrm{keV}$ from ${ }^{235} \mathrm{U}$ are overlapping each other. As in the case of ${ }^{224} \mathrm{Ra}$, activity of ${ }^{226} \mathrm{Ra}$ may be determined using the formula:

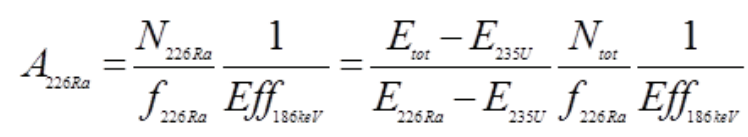

$\mathrm{N}_{\text {tot }}$ - total amount of counts in resultant peak, $\mathrm{E}_{\text {tot }}$ - location (energy) resultant peak, $\mathrm{E}_{226 \mathrm{Ra}}$ and $\mathrm{E}_{235 \mathrm{U}}$ - location of ${ }^{226} \mathrm{Ra}$ and ${ }^{235} \mathrm{U}$ peak respectively, $\mathrm{E}_{226 \mathrm{Ra}}=186.2 \mathrm{keV}$ and $\mathrm{E}_{235 \mathrm{U}}=185.7 \mathrm{keV}, \mathrm{f}_{226 \mathrm{Ra}}-$ gamma disintegration yield for line $186.2 \mathrm{keV}$ from ${ }^{226} \mathrm{Ra}, \mathrm{Eff}_{186 \mathrm{keV}}$ - efficiency at energy $186 \mathrm{keV}$, obtained during the calibration process.

Then taking into account radioactive decay yield and the sample weight, specific radioactivity was calculated. Radioisotopes are divided into four groups: (i) isotopes of ${ }^{238} \mathrm{U}$ decay chain: ${ }^{226} \mathrm{Ra},{ }^{214} \mathrm{~Pb},{ }^{214} \mathrm{Bi}$; (ii) isotopes of ${ }^{232} \mathrm{Th}$ decay chain: ${ }^{228} \mathrm{Ac},{ }^{224} \mathrm{Ra},{ }^{212} \mathrm{~Pb},{ }^{212} \mathrm{Bi},{ }^{208} \mathrm{Tl}$; (iii) the long-living naturally occurring radioisotope ${ }^{40} \mathrm{~K}$; and (iv) an artificial radioisotope being a product of nuclear fission ${ }^{137} \mathrm{Cs}$.

\section{Results}

Water and organic matter content. - Water content of the analyzed sediments ranged from 21.2 to $67.5 \%$. The lowest values $(<26 \%)$ were observed in the tidal plain sediments, significantly higher water content was in the fjord sediments. Lake sediments were characterized by the highest variety in water content, between 21.2 and $67.5 \%$, reaching also the highest values of this parameter.

Organic matter content, measured as LOI, in the sediments varied from 0.4 to $15 \%$. Similarly to the water content, the values of LOI showed the high variability, i.e. relative standard deviation equals $82 \%$, in the samples of lake sediments. The mean LOI in the surficial layer of these sediments was $6.6 \%$. 
Lower organic matter contents (mean 4.4\%) were in the fjord sediments. LOI values in the fjord sediments showed a fourfold lower variability as compared to the lake sediments. The lowest organic matter content $(0.8-1.8 \%)$ was in the tidal flat sediments with the mean LOI equal to $1.3 \%$. In the studied sediments, a typical relationship has been observed, where the increase of the content of organic matter is related to the increase of water content (Fig. 2).

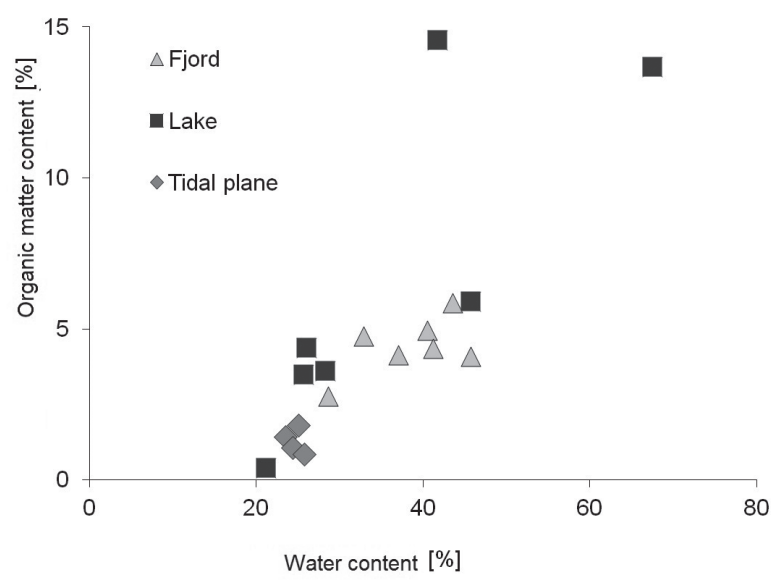

Fig. 2. Organic matter content (LOI) and water content (W) in the sediments samples.

Radionuclides. - We have found the significant diversity of radionuclide specific activity in the study area. Radioactivity of analysed isotopes in all samples is shown in Table 2 and Fig. 3. The highest total radioactivity was observed in sediment sample II 1 from Bockfjorden (1196.9 Bq/kg), the lowest in sample RI 4 from Vestfjorden tidal flat $(605.0 \mathrm{~Bq} / \mathrm{kg})$.

The biggest range of activity, from 362 to $849 \mathrm{~Bq} / \mathrm{kg}$ dry weight (d.w.), was found for naturally occurring radioisotope ${ }^{40} \mathrm{~K}$, the mean for all samples was $541 \mathrm{~Bq} / \mathrm{kg}$ d.w. (Table 2, Fig. 4). There was no correlation between ${ }^{40} \mathrm{~K}$ radioactivities and activities of other radioisotopes. Radioactivity levels of isotopes from the ${ }^{238} \mathrm{U}$ decay chain and ${ }^{232} \mathrm{Th}$ decay chain showed a linear relationship on the Draftsman plot (Fig. 5). The high correlation was observed between ${ }^{212} \mathrm{~Pb}$ and ${ }^{212} \mathrm{Bi}$, and ${ }^{208} \mathrm{Tl}$ and between ${ }^{214} \mathrm{~Pb}$ and ${ }^{214} \mathrm{Bi}$.

Radioactivities of ${ }^{137} \mathrm{Cs}$ were low, varied between 0.8 and $2.9 \mathrm{~Bq} / \mathrm{kg}$ d.w. for most of the samples, only in two water reservoirs (JIII 2 and JIII 3) radioactivity levels were higher, i.e. 7.5 and $23.6 \mathrm{~Bq} / \mathrm{kg}$ d.w., respectively. 


\begin{tabular}{|c|c|c|c|c|c|c|c|c|c|c|}
\hline$\sum_{n}^{\infty}$ & 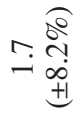 & 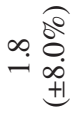 & 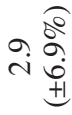 & $=\frac{\overparen{8}}{\stackrel{0}{\infty}}$ & 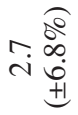 & 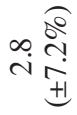 & 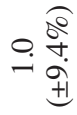 & $\stackrel{\mathbb{S}}{\Theta}$ & 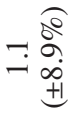 & 岕 \\
\hline$\frac{v}{q}$ & 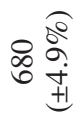 & 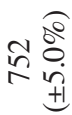 & 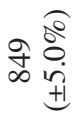 & 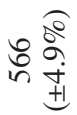 & 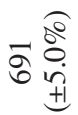 & 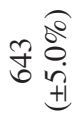 & 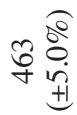 & 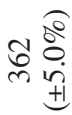 & 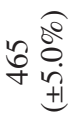 & 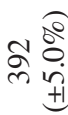 \\
\hline 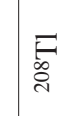 & 달 & 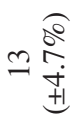 & a $\begin{array}{c}\frac{2}{2} \\
\frac{1}{+1}\end{array}$ & $=\frac{\overparen{s}}{\stackrel{+}{+1}}$ & $=\frac{\overparen{2}}{\stackrel{+}{+1}}$ & $=\underset{\substack{\frac{2}{j} \\
+1}}{+1}$ & $\pm \frac{2}{2}$ & $=\frac{\text { के }}{\stackrel{+}{+1}}$ & $=\frac{\widehat{2}}{n}$ & 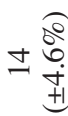 \\
\hline$\frac{\vec{n}}{\vec{N}}$ & 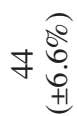 & m $\frac{\widehat{d}}{+1}$ & 周 & 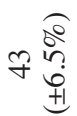 & $\exists \begin{array}{l}\text { ô } \\
\text { in } \\
\text { +1 }\end{array}$ & 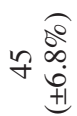 & 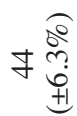 & $\exists \frac{2}{\frac{8}{0}}$ & 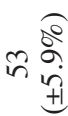 & 于 $\frac{8}{6}$ \\
\hline
\end{tabular}

긍

胥

of

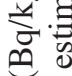

ญ Е

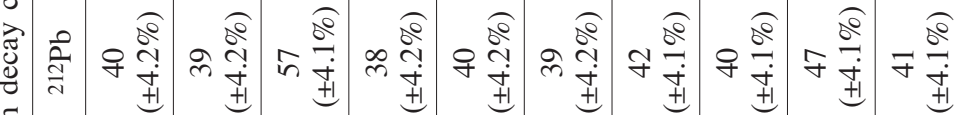

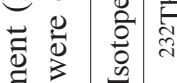

$\mathscr{\infty}$

离

응

क त

응 릉

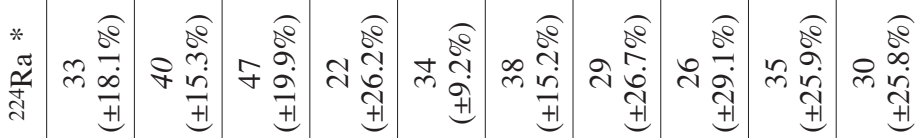

$\sum_{\substack{0 \\ 0}}^{\substack{0 \\ 0}}$

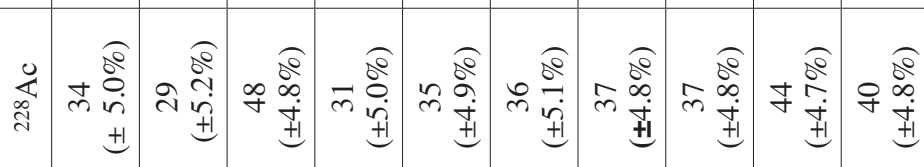

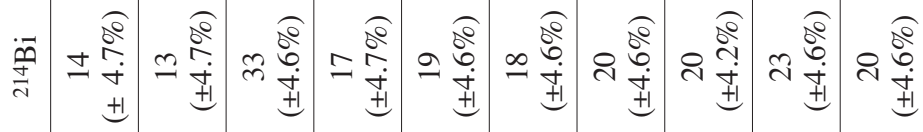

『্巳

를

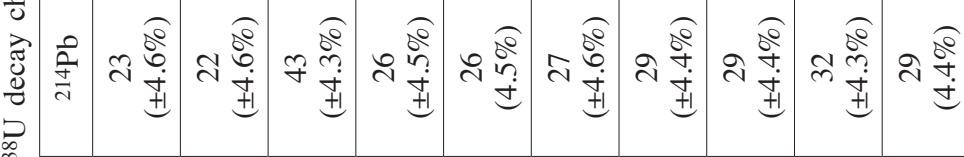

4

芑

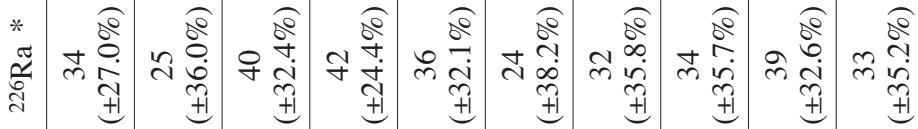

:

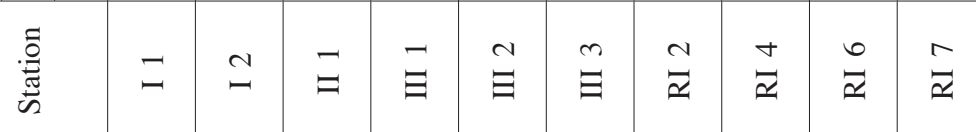




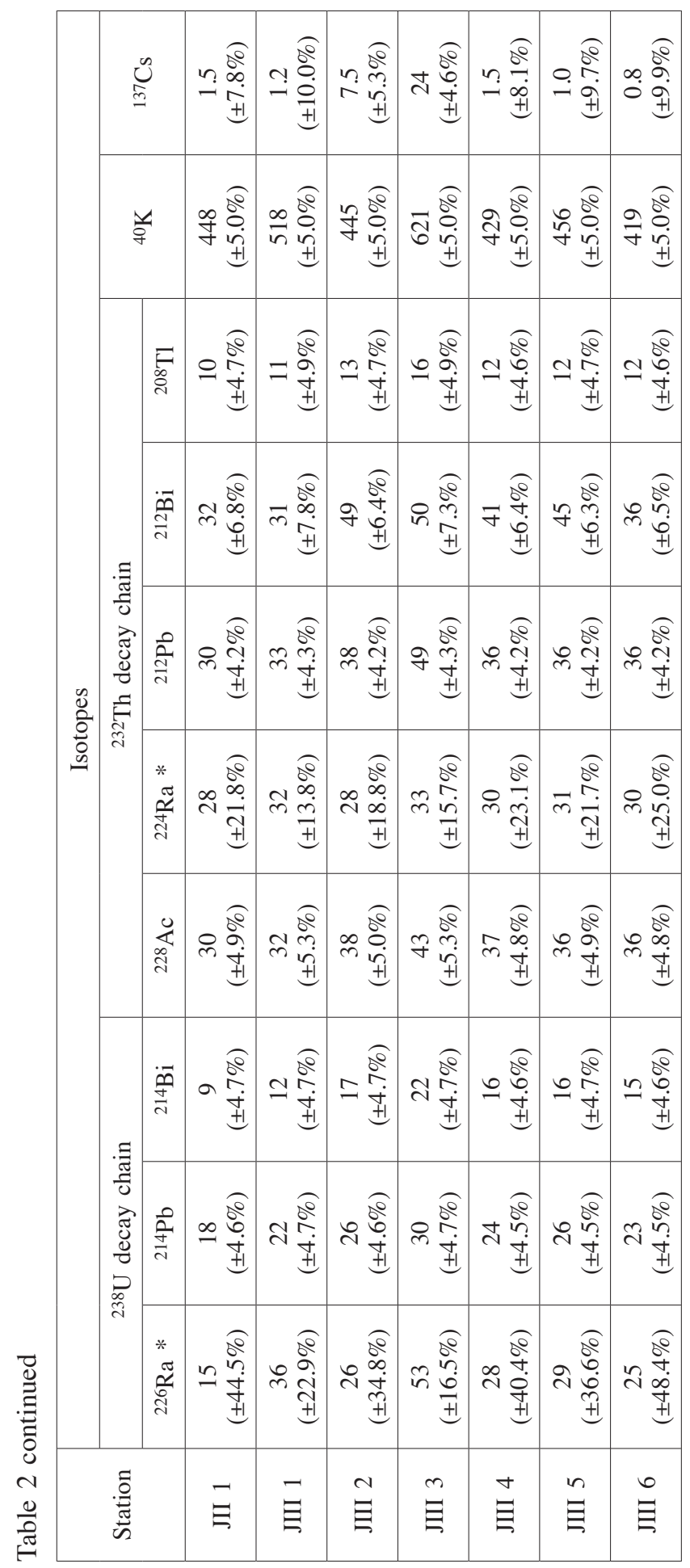




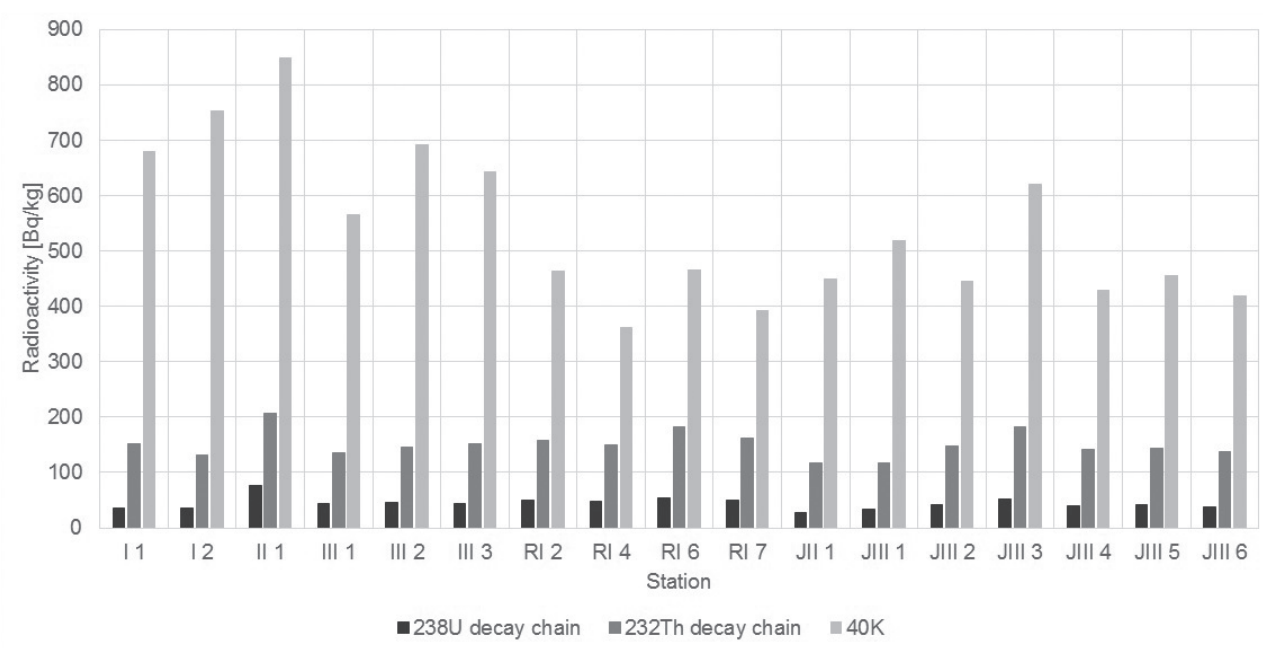

Fig. 3. Radioactivity of natural radioisotopes: ${ }^{238} \mathrm{U}$ decay chain (black) amd ${ }^{232} \mathrm{Th}$ decay chain (dark grey) and ${ }^{40} \mathrm{~K}$ (light grey) in sediments in fjords, tidal flats and lakes, northern Svalbard (August 2005).

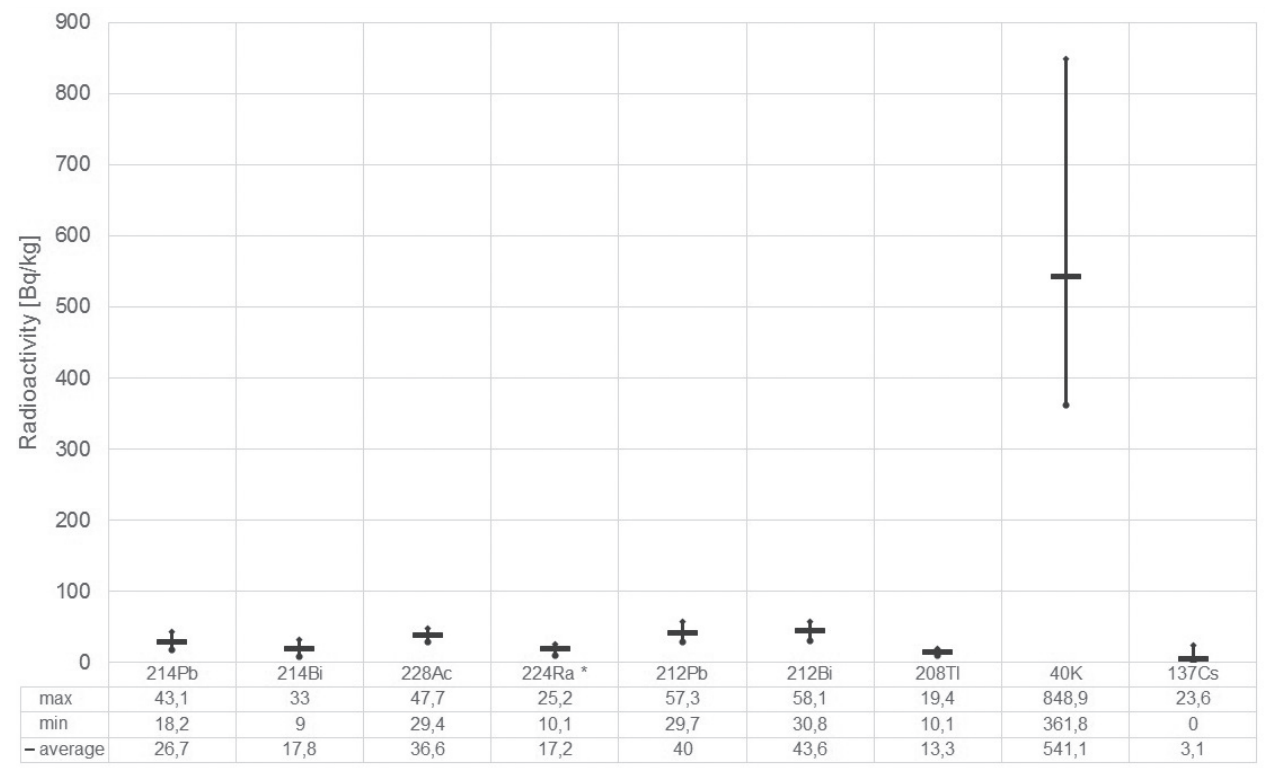

Fig. 4. Average, minimum and maximum of radioactivity of studied radioisotopes from research area. 


\section{Discussion}

Natural radioisotopes. - The natural occurring radioisotopes ${ }^{40} \mathrm{~K}$ and ${ }^{224} \mathrm{Ra}$ showed a significant variability in the sampled sediments (Table 2, Fig. 4). However, all the obtained results were within the range of values reported globally, including those for the northern Europe (UNSCEAR 2000). A strong linear correlation was found between the activities of radionuclides of $238 \mathrm{U}$ and ${ }^{232} \mathrm{Th}$ decay chains $\left(\mathrm{r}^{2}=0.94\right)$. The obtained linear relationship (Fig. 5) may point to the common source of origin of these radioisotopes in the natural environment. Such relationship was not found between activities of radionuclides of ${ }^{238} \mathrm{U}$ decay chains and ${ }^{232} \mathrm{Th}$ decay chains and ${ }^{40} \mathrm{~K} ; \mathrm{r}^{2}=0.48$ and $\mathrm{r}^{2}=0.52$, respectively.

The highest radioactivities and data variability were found for the ${ }^{40} \mathrm{~K}$ isotope (Table 2). Our data for ${ }^{40} \mathrm{~K}$ are comparable with those presented for the the terrestrial environment of Kongsfjorden (Dowdall et al. 2003).

Based on the Euclidean distance analysis (Clarke and Gorley 2006), sediment sample II-1 from Bocfjorden can be described as the most outstanding (Fig. 6). This analysis identified two groups, representing fjord and lake environments. One of them (stations II 1, RI 6, JIII 1) is characterized by the highest radioactivity of natural isotopes as compared to other samples (Table 2, Fig. 3 and Fig. 6). This may result from different bedrock of this area. Metamorphic rocks, mainly Precambrian gneisses and shales occur west of the Bockfjorden fjord, whereas Devonian sandstones are found on the east coast. Moreover, thermal springs are located in the Bocfjorden. During Pleistocene, now extinct Sverrfjellet volcano was active in this area (Banks et al. 1999a; Salvigsen and Høgvard 2005;

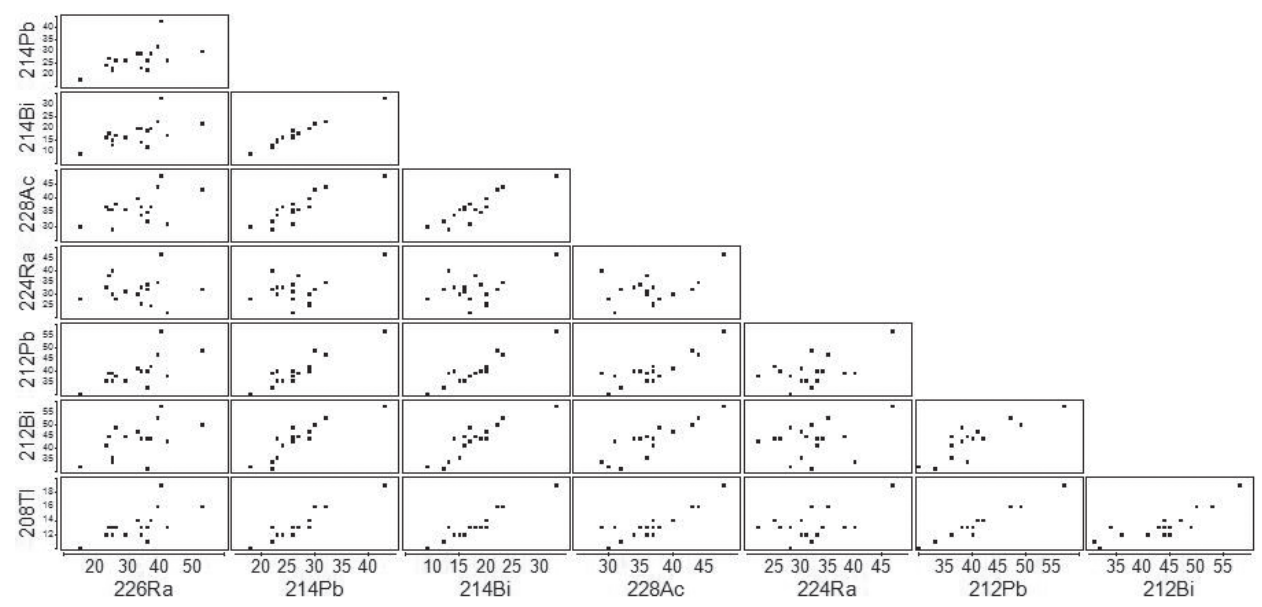

Fig. 5. Draftsman plot, correlation between natural radioisotopes from sampling stations sediments (generated by PRIMER v.6; Clarke and Gorley 2006). 


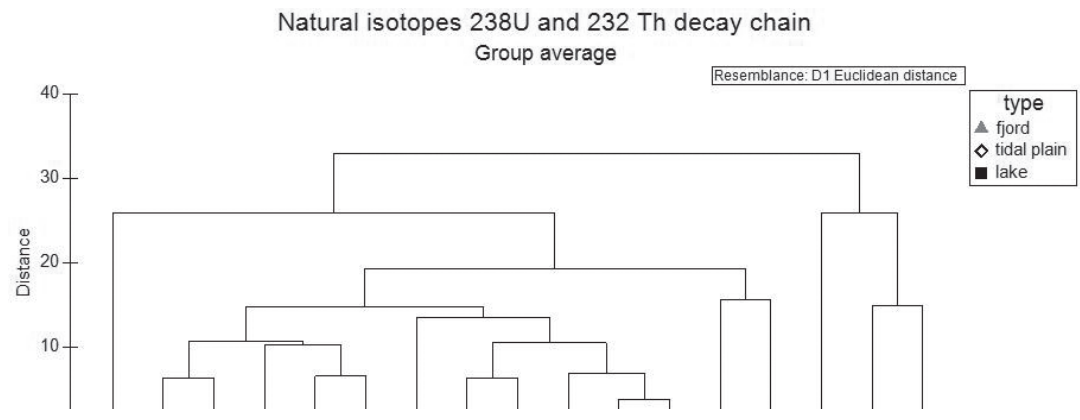

Fig. 6. Similarity clustering of the sampling stations based on naturally occurring isotopes $\left({ }^{238} \mathrm{U}\right.$ decay chain and ${ }^{232} \mathrm{Th}$ decay chain) measured in samples of sediments in on fjords, tidal flats and lakes, northern Svalbard (August 2005), generated by PRIMER v.6 (Clarke and Gorley 2006).

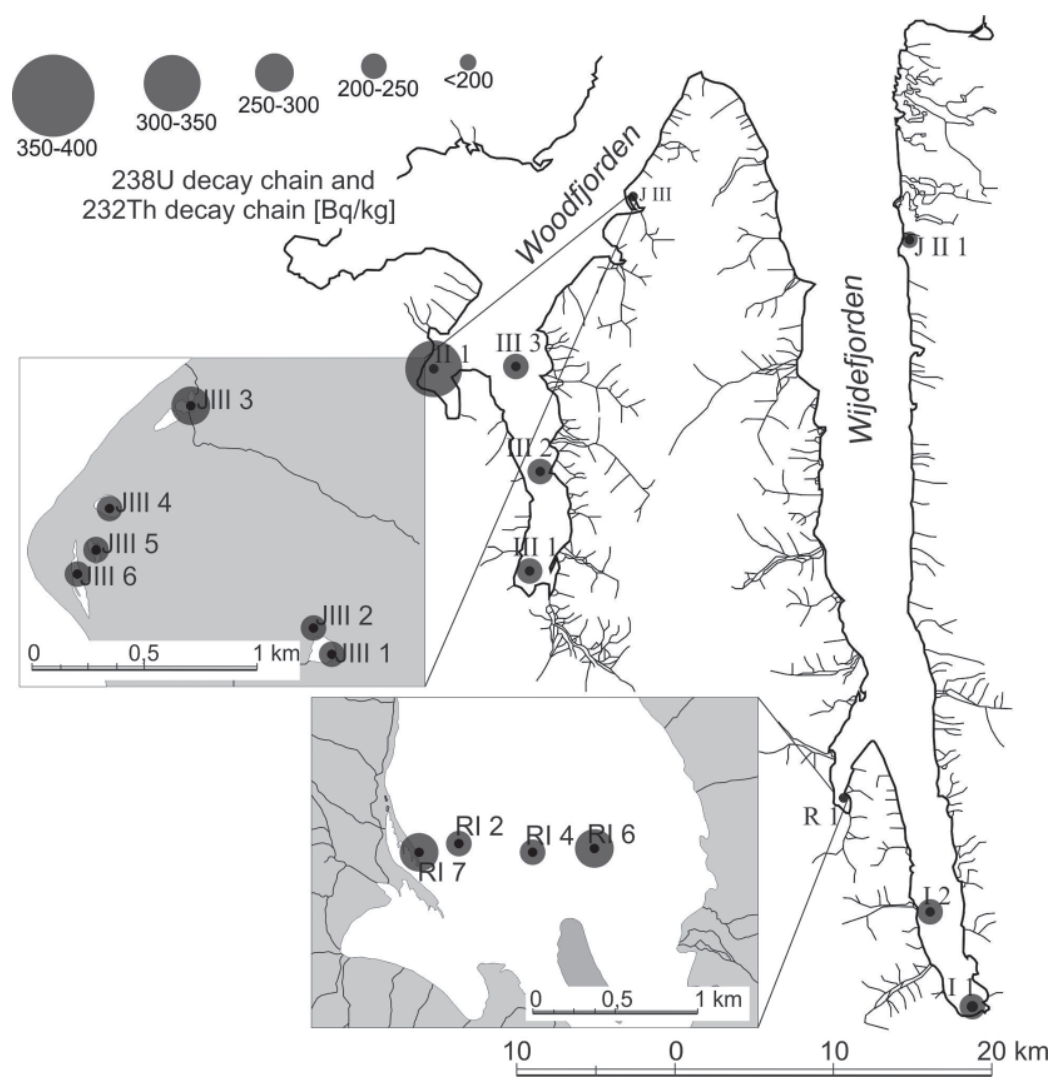

Fig. 7. Distribution of members of the ${ }^{238} \mathrm{U}$ and ${ }^{232} \mathrm{Th}$ decay chains in sediments in fjords, tidal flats and lakes, northern Svalbard (August 2005). 
Jamtveit et al. 2006). Volcanic activity effecting in establishing of particular geological structures seems to be a factor that influence existence and amount of different elements and radionuclides (Banks et al. 1995, 1999b; Brai et al. 1995; Przylibski 2004; El Galy et al. 2008; Noor and Pujadi 2012). The distribution of ${ }^{238} \mathrm{U}$ and ${ }^{232} \mathrm{Th}$ decay chain isotopes activities is presented in Fig. 7. The spatial distribution of ${ }^{40} \mathrm{~K}$ activity in sediments in the investigated area is presented in Fig. 8.

The anthropogenic isotope ${ }^{137} \mathrm{Cs}$. - Higher specific activities of anthropogenic ${ }^{137} \mathrm{Cs}$ were noted in marine sediments from Woodfjorden than from Wijdefjorden. It may be a result of different waters dominating in these fjords. The Woodfjorden is influenced by the West Spitsbergen Current i.e. Atlantic water) for almost the entire year. The Wijdefjorden is generally more affected by the Arctic water and the Atlantic water appears only during increased activity of this current.

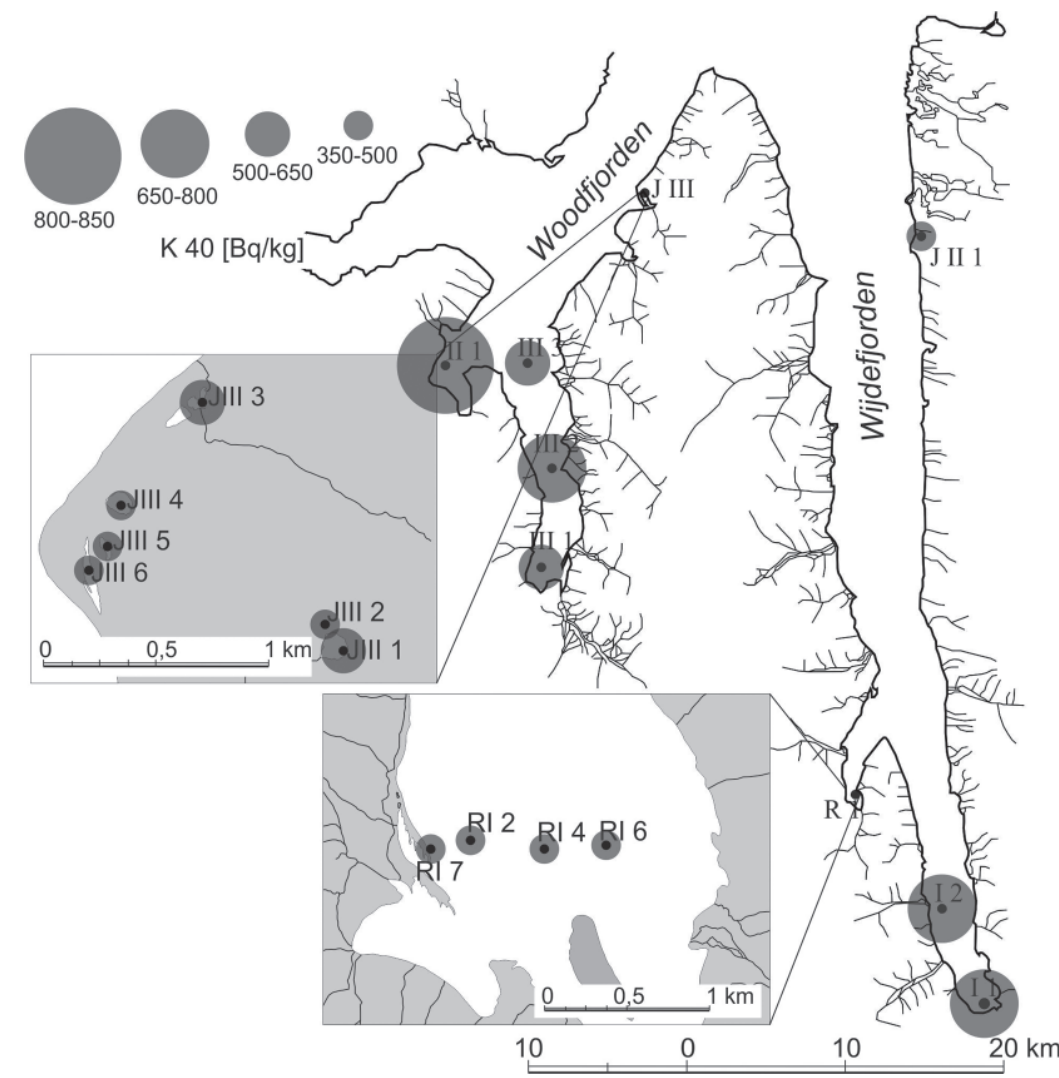

Fig. $8 .{ }^{40} \mathrm{~K}$ distribution in sediments in fjords, tidal flat and lakes, northern Svalbard (August 2005). 


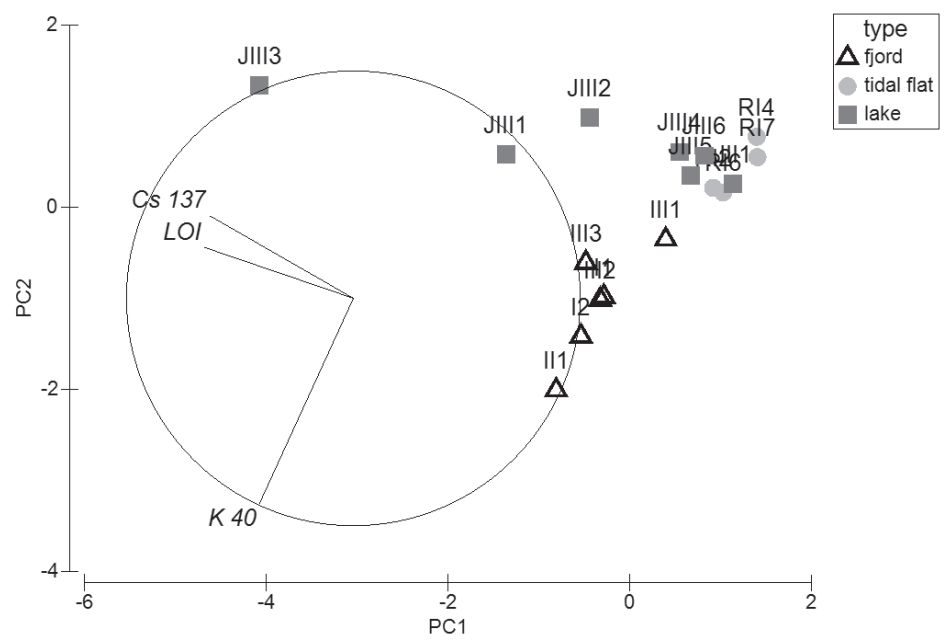

Fig. 9. PCA plot of station type similarity based on the contents of LOI, ${ }^{40} \mathrm{~K}$ and ${ }^{137} \mathrm{Cs}$ (PRIMER v.6; Clarke and Gorley 2006).

Specific activity of ${ }^{137} \mathrm{Cs}$ in the sediments on the tidal flat did not change much between sampling locations (Table 2). The activities were very low, close to the lowest level of detection. Analyses of LOI, ${ }^{40} \mathrm{~K}$ and ${ }^{137} \mathrm{Cs}$ (Fig. 9) showed two different groups: fjords (stations I 1, I 2, II 1, III 2, III 3 showing high ${ }^{40} \mathrm{~K}$ ) and lakes (stations JIII 1, JIII 2, JIII 3 showing high LOI and ${ }^{137} \mathrm{Cs}$ ); tidal flats and other stations were between this groups. There was a strong exponential relationship between the concentration of organic matter (LOI) and anthropogenic isotope ${ }^{137} \mathrm{Cs}$ in sediments, which is described by equation $\mathrm{y}=0.7316 \mathrm{e}^{0.2461 \mathrm{x}}$, $\mathrm{R}^{2}=0.7458$ (Fig. 10). The largest variability of specific activity of ${ }^{137} \mathrm{Cs}$ distribution

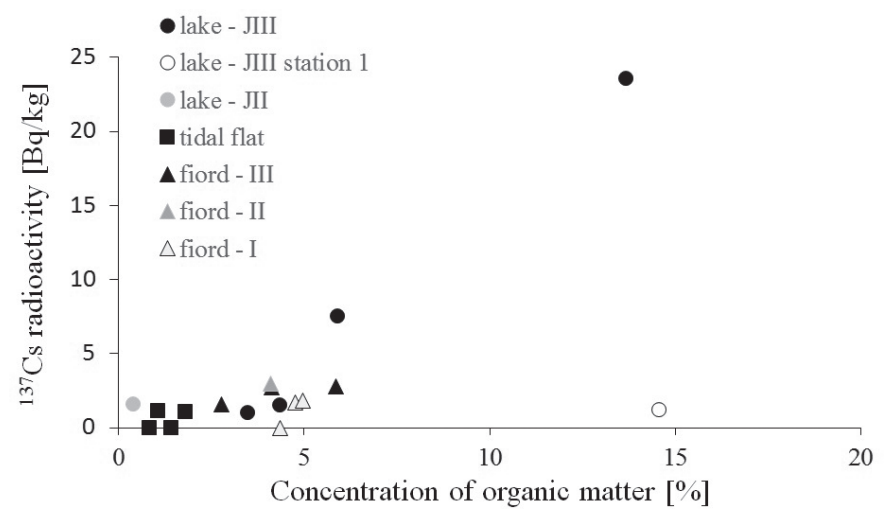

Fig. 10. Relationship between concentration of organic matter (LOI) and anthropogenic isotope ${ }^{137} \mathrm{Cs}$ in sediments on northern Svalbard (August 2005). 
was observed in sediments from freshwater reservoirs. In two sediments from two neighbouring lakes JIII-2 and JIII-3, radioactivity was significantly higher, especially in JIII-3. It is possible that these reservoirs are so-called hot points, the sites that were locally strongly polluted with ${ }^{137} \mathrm{Cs}$ after the Chernobyl nuclear reactor accident in 1986. In the adjacent freshwater reservoirs of similar characteristics (small area, shallow, rather rich vegetation), considerably lower radioactivities were noted. Moreover, random distribution of ${ }^{137} \mathrm{Cs}$ concentration can be confirmed by the lack of relationship between organic matter concentration in sediments and ${ }^{137} \mathrm{Cs}$ radioactivity (Table 2, Fig. 8). There is a significant temporal and spatial variability of ${ }^{137} \mathrm{Cs}$ concentrations (Table 3 ) which confirms the directions of contaminants migration described for anthropogenic aerosols in Arctic areas (AMAP 2004; Romanov 2004; Vana 2004). The distribution of

Table 3

${ }^{137} \mathrm{Cs}$ specific activity of bottom sediments (dry weight) within the investigated area and their comparison with bibliographic data.

\begin{tabular}{|c|c|c|c|c|}
\hline \multirow[t]{2}{*}{ Sample origin } & \multirow[t]{2}{*}{ Year } & \multicolumn{2}{|c|}{$\begin{array}{l}\text { Concentrations of } \\
\quad{ }^{137} \mathrm{Cs} \\
\text { (Bq/kg dry weight) }\end{array}$} & \multirow[t]{2}{*}{ References } \\
\hline & & $\min$ & $\max$ & \\
\hline Wijdefjorden (Svalbard) & 2005 & 0 & 1.79 & present work \\
\hline $\begin{array}{l}\text { Woodfjorden, Bockfjorden } \\
\text { (Svalbard) }\end{array}$ & 2005 & 1.591 & 2.940 & present work \\
\hline Vestfjorden (Svalbard) & 2005 & 0 & 1.101 & present work \\
\hline $\begin{array}{l}\text { Lakes in Andree Land, } \\
\text { (Svalbard) }\end{array}$ & 2005 & 0.804 & 23.54 & present work \\
\hline North-western Barents Sea & 2004 & $<0.1$ & 10.5 & $\begin{array}{l}\text { Zaborska et al. } \\
\text { (2010) }\end{array}$ \\
\hline Stepanovoy Bay & $\begin{array}{l}1992-1994 \\
2002-2004\end{array}$ & $\begin{array}{c}260 \\
20\end{array}$ & $\begin{array}{l}5450 \\
1800\end{array}$ & $\begin{array}{l}\text { Stepanets et al. } \\
\text { (2007) }\end{array}$ \\
\hline Abrosimov Bay & $\begin{array}{l}1992-1994 \\
2002-2004\end{array}$ & $\begin{array}{c}200 \\
5\end{array}$ & $\begin{array}{c}8400 \\
44\end{array}$ & $\begin{array}{l}\text { Stepanets et al. } \\
\text { (2007) }\end{array}$ \\
\hline Lakes (Finland) & 2000 & 1500 & 46000 & $\begin{array}{l}\text { Ilus and Saxen } \\
(2005)\end{array}$ \\
\hline $\begin{array}{l}\text { Subalpine lake (Norway): } \\
\text { Slit } \\
\text { Fine sand } \\
\text { Organic }\end{array}$ & 1990 & $\begin{array}{c}460000 \\
19000 \\
750000\end{array}$ & $\begin{array}{c}1800000 \\
3900000 \\
190000000\end{array}$ & Hongve et al. (1995) \\
\hline $\begin{array}{l}\text { Lakes in Tatra Mountains } \\
\text { (Poland) }\end{array}$ & 1991 & 56 & 805 & $\begin{array}{l}\text { Świrydowicz et al. } \\
\text { (2004) }\end{array}$ \\
\hline Hancza Lake (Poland) & 1989 & - & 690 & $\begin{array}{l}\text { Namiotko et al. } \\
\text { (1993) }\end{array}$ \\
\hline Patras Harbour (Greece) & 2006 & 1.9 & 11.5 & $\begin{array}{l}\text { Papaefthymiou et al. } \\
\text { (2007) }\end{array}$ \\
\hline Algiers Bay & 1996 & 0.9 & 7 & Benamar et al. (1997) \\
\hline
\end{tabular}




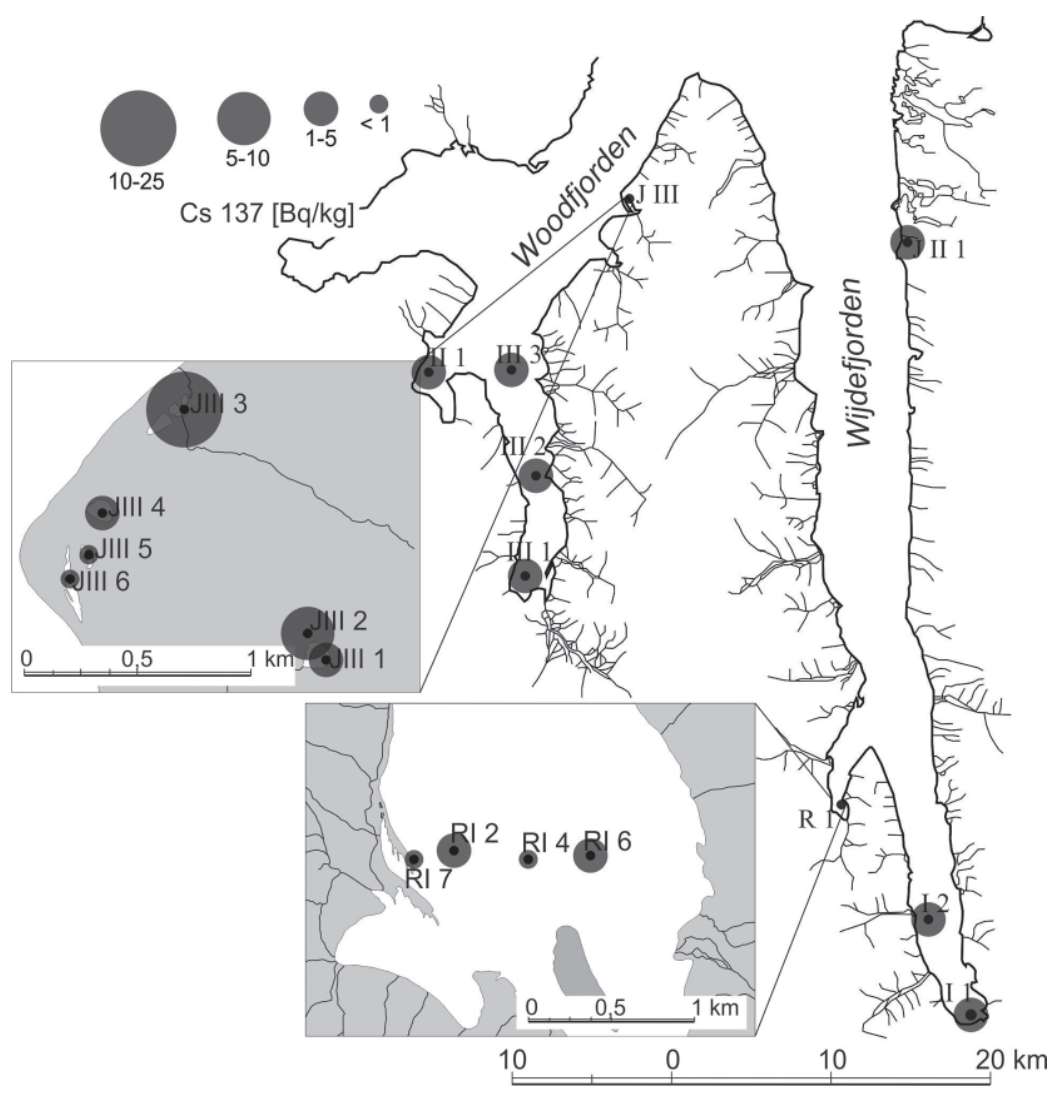

Fig. 11. ${ }^{137}$ Cs distribution in sedimenstson fjords, tidal flat and lakes, northern Svalbard (August 2005).

${ }^{137}$ Cs (Figs 11 and 12 ) is similar to persistent organic pollutants (Sapota et al. 2009). The concentrations of these substances: polycyclic aromatic hydrocarbons (PAHs), polychlorinatedbiphenyls (PCBs) and selected chloroorganic pesticides ( $\mathrm{HCH}$ isomers, DDT and its metabolites, aldrin, dieldrin, endrin, heptachlor, endosulfan I and II and methoxychlor) were lower in the sediment samples from fjords and the tidal flat than from the lakes. The correlation coefficient between ${ }^{137} \mathrm{Cs}$ and PAH + PCB is 0.656 . High correlation coefficient were found between ${ }^{137} \mathrm{Cs}$ and benzo(k)fluoranthene, correlation coefficient is 0.969 , and ${ }^{137} \mathrm{Cs}$ and CB 138 (one of the PCB components), correlation coefficient is 0.730 . The correlation coefficient among lake samples between ${ }^{137} \mathrm{Cs}$ and $\mathrm{PAH}+\mathrm{PCB}$ is higher (correlation coefficient at 0.656 ) than ${ }^{137} \mathrm{Cs}$ and LOI (correlation coefficient at 0.566 ). However, there is no correlation between ${ }^{137} \mathrm{Cs}$ and $\mathrm{PCB}$ for fjord and tidal flat samples (correlation coefficient at -0.035 ). The distribution pattern of persistent organic pollutants concentrations suggested important role of long-range atmospheric transport of these pollutants to Svalbard. It is thought to originate 


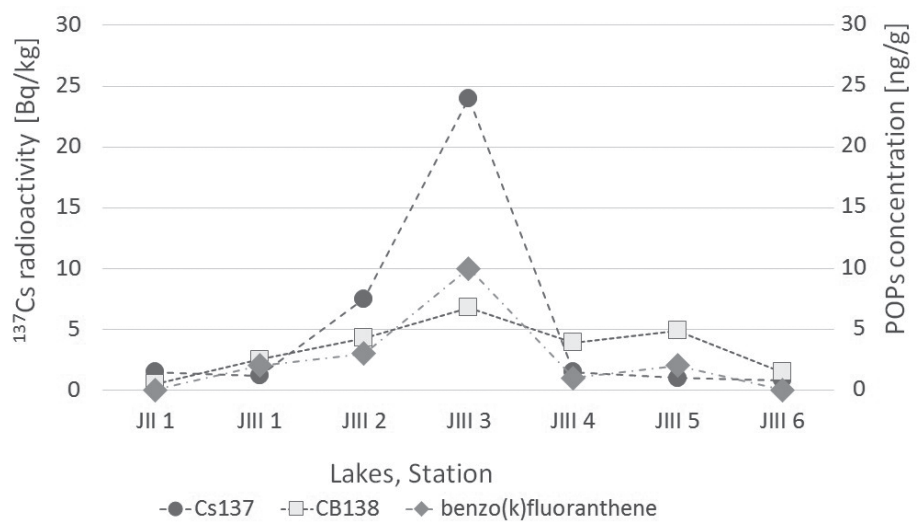

Fig. 12. Analysis of concentration of anthropogenic isotope ${ }^{137} \mathrm{Cs}$ and persistent organic pollutants (POPs) (benzo(k)fluoranthene, and CB 138) in lakes sediments on northern Svalbard.

in Russia, Western Europe and North America (Pacyna and Ottar 1985; Pacyna et al. 1985; Barrie 1986; Burkow and Kallenborn 2000). Perhaps the distribution of ${ }^{137} \mathrm{Cs}$ was also a result of atmospheric transport and deposition (AMAP 2004; Romanov 2004; Vana 2004; Sapota et al. 2009).

A comparison of the obtained results with literature data shows that the ${ }^{137} \mathrm{Cs}$ radioactivity level in North Spitsbergen is relatively low as it does not exceed $24 \mathrm{~Bq} / \mathrm{kg} .{ }^{137} \mathrm{Cs}$ concentrations in seawater (Svalbard archipelago) were 2.23 to $2.43 \mathrm{~Bq} / \mathrm{m}^{3}$ (Gwynn et al. 2004) while the radioactivity of ${ }^{137} \mathrm{Cs}$ in the North Atlantic water was below $1.5 \mathrm{~Bq} / \mathrm{m}^{3}$ (Gulin and Stokozov 2005) and in the Barents Sea around $3 \mathrm{~Bq} / \mathrm{m}^{3}$ (Strand et al. 2002). This is due to the scattering of air masses contaminated with ${ }^{137} \mathrm{Cs}$ being transported from Chernobyl to the northwest. Similar values were determined in sediment samples in Greece (Papaefthymiou et al. 2007) and Algeria (Benamar et al. 1997), while noticeably higher results were obtained in Scandinavia. The highest values reaching over $15,000 \mathrm{~Bq} / \mathrm{kg}$, which can be called extreme, were noted in the lake sediments in Norway (Hongve et al. 1995) and Finland (Ilus and Saxen 2005). Coastal lagoons in the northern Russia were characterized by the ${ }^{137} \mathrm{Cs}$ radioactivity in sediments in the range $5-5,450 \mathrm{~Bq} / \mathrm{kg}$ (Stepanets et al. 2007). On the other hand, the corresponding values in lake sediments in Poland varied from 56 to $805 \mathrm{~Bq} / \mathrm{kg}$ in high Tatra Mountain lakes (Świrydowicz et al. 2004) and reached $690 \mathrm{~Bq} / \mathrm{kg}$ in the deepest part $(109 \mathrm{~m})$ of the Hańcza Lake (Namiotko et al. 1993). 


\section{Conclusions}

Measured specific activities of natural gamma-emitting nuclides indicate their non-uniform distribution in the studied area, perhaps related to the type of bedrock. Sediment samples from stations II 1 (Bockfjorden), RI 6 (tidal flat in Vestfjorden) and JIII 1 (lake on the east coast of Woodfjorden) are characterized by high radioactivity of natural isotopes as compared to other samples. The highest specific activities of all natural radionuclides were found for sediment sample II 1 from Bockfjorden. It is possible that the radioactivities in general are strongly affected by extinct volcanic complex.

The highest radioactivities and data variability were found for the ${ }^{40} \mathrm{~K}$ isotope. In all marine and fresh-water sediment samples, the ${ }^{137} \mathrm{Cs}$ specific activities appeared to be much lower than radioactivities of natural nuclides. There was a strong exponential relationship between the concentration of organic matter and anthropogenic isotope ${ }^{137} \mathrm{Cs}$. It is possible that some reservoirs are so-called hot points, sites that were locally strongly polluted with ${ }^{137} \mathrm{Cs}$ after the Chernobyl nuclear reactor accident in 1986. The distribution of ${ }^{137} \mathrm{Cs}$ is similar to persistent organic pollutants. High correlation coefficient were found between ${ }^{137} \mathrm{Cs}$ and benzo(k)fluoranthene as well as ${ }^{137} \mathrm{Cs}$ and $\mathrm{CB} 138$, one of polychlorinatedbiphenyls.

Acknowledgements. - We thank Sven Nielsen and an anonymous reviewer for critical remarks that helped to improve this manuscript. We would like to thank Jerzy Różański, the Captain of S/Y Eltanin for help in collecting sediment samples. The work was financially supported by grant BW-1411-5-0256-5 of the Gdańsk University, Poland. This research work was part of IPY 2007-2008 Program The differentiation of limnological conditions and biodiversity in reservoirs in the polar area.

\section{References}

AMAP. 2003. AMAP Assessment 2002: The influence of Global Change on Contaminant Pathways to, Within, and from the Arctic. Arctic Monitoring and Assessment Programme (AMAP). Norway, Oslo: 65 pp.

AMAP. 2004. AMAP Assessment 2002: Radioactivity in the Arctic. Arctic Monitoring and Assessment Programme (AMAP). Norway, Oslo: 100 pp.

Andersen M., GWynn J.P., Dowdall M., Kovacs K.M. and Lydersen C. 2006. Radiocaesium $\left({ }^{137} \mathrm{Cs}\right)$ in marine mammals from Svalbard, the Barents Sea and the North Greenland Sea. Science of the Total Environment 363: 87-94.

Banks D., Reimann C., Royset O., Skarphagen H. and Magne SÆTher O. 1995. Natural concentrations of major and trace elements in some Norwegian bedrock groundwaters. Applied Geochemistry 10: 1-16. 
Banks D., Siewers U., Sletten R.S., Haldorsen S., Dale B., Heim M. and Swensen B. 1999a. The thermal springs of Bockfjorden, Svalbard: II: selected aspects of trace element hydrochemistry. Geothermics 28: 713-728.

Banks D., Hall G., Reimann C. and Siewers U. 1999b. Distribution of rare earth elements in crystalline bedrock groundwaters: Oslo and Bergen regions, Norway. Applied Geochemistry 14: $27-39$.

BARRIE L.A. 1986. Arctic air pollution: an overview of current knowledge. Atmospheric Environment 20: 643-663.

Benamar M.A., Zerrouki A., Idiri Z. and TobBeche S. 1997. Natural and artificial radioactivity levels in sediments in Algiers Bay. Applied Radiation and Isotopes 48(8): 1161-1164.

Brai M., HAuser S., Bellia S., PuCCiO P. and Rizzo S. 1995. Natural gamma radiation of rocks and soils from volcano (Aeolian Islands, Mediterranean Sea). Nuclear Geophysics 9 (2): 121-127.

BURKOW I.C. and KALLENBORN R. 2000. Sources and transport of persistent pollutants to the Arctic. Toxicology Letters 112-113: 87-92.

CHOIŃsKi A. 2000. Lakes of the globe. PWN. Warszawa: 204 pp. (in Polish).

ChURSKI Z. 1976. Watershed's evolution in front of the field of the Skeidararjökull glacier at Iceland. Problemy Geografii Fizycznej. VII(3-4): 45-61 (in Polish).

ClARKe K.R. and GoRLEY N.R. 2006. PRIMER v6: User Manual/Tutorial. PRIMER-E. Plymouth.

DOWDALL M., GERLAND S. and LIND B. 2003. Gamma-emitting natural and anthropogenic radionuclides in the terrestrial environment of Kongsfjord, Svalbard. The Science of the Total Environment 305: 229-240.

DRAGOVIĆ S. and ONJIA A. 2006. Classification of soil samples according to their geographic origin using gamma-ray spectrometry and principal component analysis. Journal of Environmental Radioactivity 89: 150-158.

DrZYMAŁA S. 2007. Professional soil sampling, Science School Materials "Methods of sample preparation for instrumental analysis", Poznań: 141 pp. (in Polish).

El Galy M.M., El MeZayn A.M., SaID A.F., El Mowafy A.A. and Mohamed M.S. 2008. Distribution and environmental impacts of some radionuclides in sedimentary rocks at Wadi Naseib area, southwest Sinai, Egypt. Journal of Environmental Radioactivity 99: 1075-1082.

FøYN L. and SVÆREN I. 1997. Distribution and sedimentation of radionuclides in the Barents Sea. ICES Journal of Marine Science 54: 333-340.

GRACA B., BURSKA D. and MatuszewsKA K. 2004. The impact of dredging deep pits on organic matter decomposition in sediments. Water Air Soil Pollution 158: 237-259.

GULIN S.B. and STOKOZOV N.A. 2005. 137-Cs concentrations in Atlantic and western Antarctic surface waters: results of the 7th Ukrainian Antarctic Expedition, 2002. Journal of Environmental Radioactivity 83: 1-7.

GWYNn J.P., Dowdall M., DaVIDS C., SEALnÆS Ø.G. and Lind B. 2004. The radiological environment of Svalbard. Polar Research 23(2): 167-180.

Haugan P.M. 1999. Structure and heat content of the West Spitsbergen Current. Polar Research 18: $183-188$.

HongVe D., BlacAR I.A. and BRITTAin J.E. 1995. Radiocaesium in the sediments of Øvre Heimdalsvatn, a Norwegian Subalpine Lake. Journal of Environmental Radiactivity 27: 1-11.

ILus E. 2007. The Chernobyl accident and the Baltic Sea. Boreal Environment Research 12: 1-10.

ILUS E. and SAXEN R. 2005. Accumulation of Chernobyl-derived ${ }^{137} \mathrm{Cs}$ in bottom sediments of some Finnish lakes. Journal of Environmental Radioactivity 82: 199-221.

JAMTVEIT B., HAMmER Ø., ANDERSSON C., DYSTHE D.K., HELDMANN J. and FogEl M.L. 2006. Travertines from the Troll thermal springs, Svalbard. Norwegian Journal of Geology 86: 387-395.

JONES E.P. 2001. Circulation in the Arctic Ocean. Polar Research 20: 139-146. 
LØYNING T.B. 2001. Hydrography in the north-western Barents Sea, July-August 1996. Polar Research 20(1): 1-11.

MidTTUN L. 1990. Surface temperatures of the Barents Sea. Polar Research 8: 11-16.

MYŚLIŃsKA E. 1998. Laboratoryjne Badania Gruntów (Laboratory of soil research), PWN, Warszawa: $243 \mathrm{pp}$.

NAmiotko T., MıюsteK A. and WiśNIEWSKA B. 1993. Changes of Lake Hańcza (NE Poland) ecological state in the last fifty years with particular attention being paid to the profundal Ostracoda fauna. Polskie Archiwum Hydrobiologii 40: 267-290.

NOOR J.A.E. and PUJADI E. 2012. Survey of natural occurring radionuclides and particle concentrations from erupting Mount Bromo in East Java, Indonesia. International Journal of Basic \& Applied Sciences IJBAS-IJENS 12: 25-28.

NOWIŃSKI K. 2002. Physicolimnological features of chosen reservoirs in the area of Hornsund (south-western Spitsbergen). Limnological Review 2: 285-294.

PACYNA J.M. and OTTAR B. 1985. Transport and chemical composition of the summer aerosol in the Norwegian Arctic. Atmospheric Environment 19: 857-865.

PACYNA J.M., OtTAR B., TOMZA U. and MAEnhaut W. 1985. Long-range transport of trace elements to Ny-Ålesund, Spitsbergen. Atmospheric Environment 19: 2109-2120.

PN-ISO 11644 1999. Soil quality. Preliminary preparation of samples for physical and chemical analysis (in Polish).

Papaefthymiou H., Papatheodorou G., Moustakli A., Christodoulou D. and Geraga M. 2007. Natural radionuclides and ${ }^{137} \mathrm{Cs}$ distributions and their relationship with sedimentological processes in Patras Harbour, Greece. Journal of Environmental Radioactivity 94: 55-74.

Proshutinsky A.Y., Polyakov I.V. and Johnson M.A. 1999. Climate states and variability of Arctic ice and water dynamics during 1946-1997. Polar Research 18: 135-142.

PRZYLIBSKI T.A. 2004. Concentration of ${ }^{226} \mathrm{Ra}$ in rocks of the southern part of Lower Silesia (SW Poland). Journal of Environmental Radioactivity 75: 171-191.

Romanov V.F. 2004. Northern hemispheric air circulation. In: Skreslet S. (ed.) Jan Mayen Island in Scientific Focus. NATO Science Series IV. Earth and Environmental Sciences 45: 55-66.

SALVIGSEN O. and HøGVARD K. 2005. Glacial history, Holocene shoreline displacement and palaeoclimate based on radiocarbon ages in the area of Bockfjorden, north-western Spitsbergen, Svalbard. Polar Research 25(1): 15-24.

SAPOTA G., WOJTASIK B., BURSKA D. and NOWIŃSKI K. 2009. Persistent Organic Pollutants (POPs) and Polycyclic Aromatic Hydrocarbons (PAHs) in surface sediments from selected fjords, tidal plains and lakes of the North Spitsbergen. Polish Polar Research 30(1): 59-76.

SIMA O. 1992. Photon attenuation for samples in Marinelli beaker geometry: an analytical computation. Health Physics 62: 445-449.

Stepanets O., Borisov A., Ligaev A., Solovjeva G. and Travkina A. 2007. Radioecological investigations in shallow bays of the Novaya Zemlya Archipelago in 2002-2005. Journal of Environmental Radioactivity 96: 130-137.

Strand P., Howard B.J., Aarkrog A., Balonov M., Tsaturov Y., Bewers J.M., Salo A., SiCKEL M., BERGMAN R. and RISSANEN K. 2002. Radioactive contamination in the Arctic - sources, dose assessment and potential risks. Journal of Environmental Radioactivity 60: $5-21$.

ŚWIRYDOWICZ S., WiŚNIEWSKA-WOJTASIK B. and NAMIOTKO T. 2004. The content of ${ }^{137}$ Cs in bottom sediments of selected Tatra Mountains ponds. In: Wiśniewski R, Jankowski J (eds.) Protection and restoration of lakes, Poland, Grudziądz: 217-221 (in Polish).

UNSCEAR 2000. Report: Sources and effects of ionizing radiation, Report to General Assembly with Scientific Annexes, United Nations, New York: 654 pp. 
VANA M. 2004. Natural and anthropogenic aerosols in Arctic areas. In: Skreslet S (ed.) Jan Mayen Island in Scientific Focus. NATO Science Series, IV. Earth and Environmental Sciences 45: 67-77.

WALCZOWSKI W. and PIECHURA J. 2006. New evidence of warming propagating toward the Arctic Ocean. Geophysical Research Letters 33: L12601.

Walczowski W. and Piechura J. 2007. Pathways of the Greenland Sea warming. Geophysical Research Letters 34: L10608.

Zaborska A., Mietelski J.W., Carroll J., Papucci C. and PempKowiak J. 2010. Sources and distributions of ${ }^{137} \mathrm{Cs},{ }^{238} \mathrm{Pu},{ }^{239,240} \mathrm{Pu}$ radionuclides in the north-western Barents Sea. Journal of Environmental Radioactivity 101: 323-331.

Received 12 September 2016

Accepted 7 July 2017 